\title{
The Implementation of Principal's Supervision in SD Negeri Tungkal Ilir Banyuasin (Teacher's Competency Development Study)
}

\author{
Devi \\ SDN 10 Sembawa, Banyuasin \\ e-mail: devihamdan171017@gmail.com \\ Edi Harapan \\ Universitas PGRI Palembang \\ e-mail: ehara205@gmail.com \\ Dessy Wardiah \\ Universitas PGRI Palembang \\ e-mail: dessywardiah77@gmail.com \\ Article History: Received on 6 July 2021, Revised on 22 July 2021 \\ Published on 29 July 2021
}

\begin{abstract}
This study finds out more about the role of principal supervision through the principal functions in improving the professionalism of teachers. The instruments in this study were interview sheet, observation sheet, and documentation study. Data analysis is made after the data and information obtained in accordance with the needs are compiled, classified and formulated on the basis of data interpretation. The results showed that the work program prepared by the principal in fostering teachers has a positive impact on teacher competence. Supervision of the principal is carried out periodically in fostering teachers. This paper contributes to the school in fostering teachers so that they can be more professional in carrying out their duties through supervision carried out by the principal.
\end{abstract}

Keywords: Principal's Supervision, Teacher's Competency Development, Primary School

\section{A. Introduction}

School is a formal educational institution that organizes teaching and learning process activities as an effort to achieve educational goals. The high and low quality of education is much influenced by the quality of the learning process carried out by the teacher, because the teacher directly provides guidance and assistance to students in an effort to achieve educational goals (Ekosusilo, 2013).

The principal is the center of leader who regulates and manages activities to be directed, focused and experienced a significant improvement. Therefore, the principal plays an important role in improving the performance of teachers to be more enthusiastic and professional in teaching and developing themselves in transferring knowledge to students.

The principal leads the institution with a very large role for improving school progress. This is because the principal's task is to oversee the activities that have been programmed to be directed, focused and successful (Mulyasa, 2013). 
Volume 2 (1) 2021

E-ISSN: 2723-6919 P-ISSN:2746-0827

Principals also play an important role in improving teacher performance to be more enthusiastic and professional in teaching. With a very basic reason that teachers have a very important role in determining the quality of teaching carried out, therefore they must think and plan carefully in increasing student learning opportunities by improving the quality of teachers.

This shows that teachers are expected to be able to play an active role as managers of the teaching and learning process, act as facilitators who always try to create class organization, use teaching methods as well as teacher attitudes and characteristics in managing the teaching and learning process (Suharsaputra, 2018)

School devices such as principals, teacher boards, students, employees must support each other to work together to achieve the goals that have been set. Therefore, it can be said that the success or failure of an organization in achieving predetermined goals is very dependent on the ability of its leaders to foster a climate of cooperation so that they can easily mobilize existing human resources, so that their utilization can run effectively and efficiently (Mulyasa, 2013).

The supervisory role of the principal is assessed from the performance that produces outcomes for the organization and rewards for personnel in the form of salaries, benefits, job security, recognition from coworkers and superiors, as well as promotional opportunities for individual employees. This is in line with motivating factors and health factors.

Employees generally measure job satisfaction in terms of these rewards, which are the most tangible things they receive from work. Individuals can get job satisfaction from their sense of personal achievement through work and also from feedback about their performance (Zahroh, 2015).

One of the competencies that must be possessed by school principals is supervisory competence. The supervisory competence according to the Minister of National Education Number 13 of 2007 includes planning an academic supervision program in order to increase teacher professionalism, carrying out academic supervision of teachers using appropriate supervision approaches and techniques and following up on the results of academic supervision of teachers in order to increase the professionalism of efficient teachers (Mulyasa, 2013)

To support these competencies, principals must have knowledge and skills in planning, implementing and following up on supervision in an effort to improve school quality. To improve the quality of teachers, principal supervision activities are carried out through service and coaching activities by providing opportunities for teachers to be able to develop professionally (Suharsaputra, 2018)

Supervision is an activity that must be carried out by a leader related to the leadership role he carries in order to maintain the quality of the products produced by the institution. It aims to improve quality and performance. With guidance and assistance, the quality of existing human resources can always be maintained and improved (Bafadal, 2014).

In the supervision process, the supervisor can act as a source of information, a source of ideas, a source of guidance in various matters in order to improve the professional abilities of teachers. Supervision as coordination, the principal as a supervisor must lead a number of teachers, each of whom has their own duties and responsibilities. 
Volume 2 (1) 2021

E-ISSN: 2723-6919 P-ISSN:2746-0827

Supervisors must ensure that every teacher can carry out their duties properly in a cooperative work situation. Supervision as an evaluation, to determine the ability of the teacher to be fostered, an evaluation needs to be carried out so that the supervision program matches the needs of the teacher. In addition, through evaluation, it can also be known the teacher's ability after receiving assistance and training from supervisors (Kompri, 2015).

To achieve standards of eligibility and good performance, schools need to be led by a qualified principal who has extensive knowledge of school management, has a work culture and organizational culture, and has the resilience to face all forms of problems, obstacles and difficulties when carrying out his duties as a leader or a manager (Ahmad, 2013).

Suharsaputra (2018) suggests that the involvement of principals and teachers in developing learning effectiveness in schools also encourages a higher sense of ownership of their schools which in turn encourages them to use existing resources as efficiently as possible to achieve maximum results. Principal leadership is an interesting thing to study as an effort to get quality schools.

Furthermore, Yuliati (2018) explained that the principal as a supervisor has the responsibility to increase the ability of teachers to manage learning activities at school and has a very important role in the development and progress of the school. Therefore, the principal must supervise properly and correctly in accordance with the principles and techniques as well as the right approach. The guidance carried out by the principal to the teacher can improve the performance and dedication of the teacher in education. The task of a supervisor is to help, encourage and provide confidence to teachers that the teaching and learning process can provide the development of various experiences, knowledge, attitudes and skills of teachers and the teaching and learning process carried out by the teacher must be assisted professionally so that teachers can develop in their work, namely to improve effectiveness and efficiency of the teaching and learning process. Supervision carried out by school principals is to improve the competence of teachers in teaching and learning activities, so that they are expected to fulfill their teaching mission or national education mission in a wider scope.

As we all know that the problem of the teaching profession in carrying out teaching and learning activities will always and continue and the supervision assistance from the principal is very important in developing the professionalism of teachers in carrying out their duties to the fullest. The principal wants the support of the teacher's performance that there is always a consistent improvement in carrying out learning at school (Burhanuddin, 2015).

Burhanuddin (2015) further stated that the purpose of supervision is to develop a better teaching and learning situation through coaching and improving the teaching profession (1) Increasing the efficiency and effectiveness of teaching and learning; (2) Controlling the implementation of the technical educational field in schools in accordance with the provisions and policies that have been determined; (3) Ensuring that teaching and learning activities take place in accordance with applicable regulations, so that they run smoothly and obtain optimal results; (4) Assessing the success of the school in carrying out its duties; and (5) Provide direct guidance to correct problems, shortcomings and mistakes and help solve problems faced by schools so that further errors can be prevented.

This is reinforced by the Regulation of the Minister of National Education Number 13 of 2007 concerning the standards of school principals which has included 5 competencies that must be 
possessed by school principals, personality, managerial, entrepreneurial, supervisory and social competencies.

The signs for assessing the performance of the principal of the Director General of Primary and Secondary Education in 2000 are 1) Ability to develop teaching supervision programs, 2) Ability to implement teaching supervision programs, 3) Ability to utilize the results of supervision. Therefore, the subject of study in this research is supervision which includes 1) Elements supervised by the principal of teachers in improving teacher performance, 2) Appropriate supervision strategies for improving teacher performance, 3) Feedback and follow-up supervision principals in order to improve teacher performance (Mulyasa, 2017).

Ahmad further stated that under the leadership of a professional principal, students and teachers can develop according to their potential, so that education in the schools he leads will increase. As a leader, you must be able to provide guidance to guide, direct, and encourage the emergence of a passionate, confident will to teachers, staff, and students in carrying out their duties and provide inspiration in achieving goals (Ahmad, 2013).

Referring to the Ministry of National Education No. 143/MPK/1990 and the Decree of the Minister of National Education No. 162/U/2003 and the latest provisions with the Minister of National Education Regulation No. 13 of 2007 that the Principal is a teacher who is assigned the position of Head of School with a term of office of four years to control the school. As a teacher, he is obliged to carry out face-to-face meetings in class for six hours per week. The principal as staff, that he is a formal official whose appointment, guidance, and responsibilities are bound by a series of provisions and procedures. He is responsible and accountable to his superiors.

In Government Regulation No. 19 of 2005 and Kurniasih (2017) professional teachers must have 4 competencies, namely 1) pedagogy, 2) personality, 3) social, and 4) professional. Therefore, teachers who have competence are expected to be able to direct and develop the potential possessed by their students and easily overcome the learning difficulties faced by these students.

According to Supardi (2013) there are three kinds of duties of the teaching profession that cannot be avoided, namely professional tasks, social tasks, and personal tasks. Furthermore, qualified professional teachers according to Mulyasa (2013) are teachers who have the ability to create a learning climate in the classroom, have the ability to manage learning, have the ability to provide feedback and reinforcement and have the ability to improve themselves.

Jamal (2009) suggests that teachers are professional educators with the main task of educating, teaching, guiding, directing, training, assessing, and evaluating student learning outcomes. The professional duties of teachers include educating, teaching and training/guiding, as well as researching.

There are three characteristics of teacher professionalism in general, first, a professional teacher must master the field of science that he will teach well. Second, a professional teacher must have the ability to convey or teach the knowledge he has to his students effectively and efficiently. Third, a professional teacher must adhere to the professional code of ethics, the teacher must have a strong interest in carrying out his duties in accordance with the rules of teacher professionalism required (Samana, 2014). 
Volume 2 (1) 2021

E-ISSN: 2723-6919 P-ISSN:2746-0827

Sukadi (2016) explained that teachers should have professionalism in teaching so that the quality of education can be improved. For the world of education, teachers are not foreign. The teacher is a human figure who should be admired and imitated. Be admired in the sense that all his words can be trusted, imitated means that all his behavior must be able to be an example or role model for the community.

According to Rochman (2011) it is the teacher who directly deals with students to transfer knowledge and technology as well as educate with positive values through incomparable guidance and example. The existence of teachers in education is very crucial, because their obligations are not only to transfer knowledge, but are also required to internalize values to students.

Based on preliminary data, the researchers obtained at SDN 10 Tungkal Ilir, that the learning process at SDN 10 Tungkal Ilir was assisted by teachers who taught 11 teachers consisting of 7 civil servant teachers and 4 honorary teachers, while 4 civil servant teachers were certified. The learning process is carried out from 7 am to $12 \mathrm{am}$. Meanwhile, extracurricular activities are carried out from $3 \mathrm{pm}$ to $5 \mathrm{pm}$.

According to the explanation that the researcher received from the principal, the teachers who teach at SDN 10 Tungkal Ilir have not shown their professionalism. This is because, there are still teachers who provide learning materials by means of lectures and assignments. Teachers rarely deliver subject matter using visual media. Although the infrastructure is considered inadequate, the learning process is still prioritized, even if it is perfunctory. The principal also explained that with his busy schedule as a leader in carrying out his duties and obligations, the principal acknowledged that his supervisory role had been lacking so far, so that supervision, guidance and direction that should have been conveyed to teachers were not carried out properly. In addition, the disciplines of education staff are considered not linear with the tasks. As the principal, he tries and strives to increase the understanding and knowledge of teachers by sending teachers to attend training and seminars, and teacher professionalism can be improved.

Still according to information from the principal, that the implementation process in carrying out his duties refers to setting the direction of the school as an educational institution by formulating the vision, mission, goals and achievement strategies. Organizing schools in the sense of making an organizational structure, assigning staff and assigning the duties and functions of each staff without taking the time to evaluate on a scheduled basis. Supervising, controlling, guiding all school staff and residents is only limited to class visits and brief reviews in daily activities.

The discipline of teachers who teach is not linear, because there are still teachers who only have high school education, while teachers with undergraduate education such as graduates of the Faculty of Economics, Accounting Management study program are given the task of teaching social studies subjects. From the observations at SD Negeri 10 Tungkal Ilir there are still $36.4 \%$ of teachers who teach non-linearly according to the level and path of education. The teacher conveys the subject matter without using visual media. Even though in today's digital era, every teacher who teaches should use media assistance, both print media and technologybased media.

Looking at this reality, the researcher wants to find out more about the role of principal supervision through the principal functions and duties in improving the professionalism of 
The reason to review this research that it will contribute to the school in fostering teachers so that they can be more professional in carrying out their duties through supervision carried out by the principal (Yusuf et al, 2020). Besides that, the researcher also sees that there are no other researchers who have conducted research with the same title. This research was strengthened by Muslikhah (2018) in his research journal entitled The Role of Principals as Supervisors in Developing Teacher Professionalism at SD Negeri 02 Merlia (2017) with the title Supervision Roles of Madrasah Principals in Improving Teacher Professionalism at MTs Futuhiyah 2 Gunung Batu Bukit Kemuning North Lampung.

\section{B. Methods}

This research was conducted at SD Negeri 10 Tungkal Ilir. The time of the study was carried out in August 2020 to October 2020. This is a qualitative research, with the aim of obtaining an in-depth understanding and interpretation of the meaning of the phenomena in the field. Sources of data obtained from this study from primary and secondary data. Primary data were obtained from the Principal of SD Negeri 10 Tungkal Ilir with 8 teachers. While secondary data were obtained from relevant research and literature review. Sources of primary data in this study in the form of interviews obtained from the principal, and teachers. In addition, data in the form of documentation such as research permits, school profiles and so on are supporting data to complete the results of research reports. The instruments in this study were interview sheet, observation sheet, and documentation study. The data that has been collected cannot be directly presented in the research report, but must be processed and analyzed first. Data analysis is made after the data and information obtained in accordance with the needs are compiled, classified and formulated on the basis of data interpretation.

\section{Results and Discussion}

Based on the findings of the research both from interview sheet, observation sheet and document study, it can be explained that the implementation of the supervision of the principal of SD Negeri Tungkal Ilir, Banyuasin Regency (Teacher Competency Development Study) can be explained that the work program prepared by the principal in fostering teachers has a positive impact on teacher competence. Supervision of the principal is carried out periodically in fostering teachers. Teachers are able to make lesson plans in accordance with the established curriculum. Teachers have been able to carry out their duties as educators. The teacher's personality is considered good in delivering learning materials to students. In terms of competence, teachers have been able to communicate well with school residents, both fellow teachers and with students. Although there are teachers who teach not in accordance with the disciplines they have, the principal always provides coaching for the competence of these teachers, so that they are able to carry out their duties. the supervision carried out by the principal has been arranged on a scheduled basis and the obstacles faced together with the teacher council to be resolved and the best way is sought so that learning activities can run as expected. Principals always provide motivation to teachers in carrying out learning (Kurniadi et al, 2020). The principal always tries to motivate teachers who do not have an educator certificate so that they can have a certificate. 
Journal of Social Work and Science Education

Volume 2 (1) 2021

E-ISSN: 2723-6919 P-ISSN:2746-0827

Based on the theoretical study of Mulyasa (2013) that the principal leads his institution with a very large role for improving school progress. This is because the principal's job is to oversee the activities that have been programmed to be directed, focused and successful (Suratman et al, 2020).

Principals also play an important role in improving teacher's performance to be more enthusiastic and professional in teaching (Zulaiha et al, 2020). With a very basic reason that teachers have a very important role in determining the quality of teaching carried out, therefore they must think and plan carefully in increasing student learning opportunities by improving the quality of teachers. This shows that teachers are expected to be able to play an active role as managers of the teaching and learning process, act as facilitators who always try to create class organization, use teaching methods as well as teacher attitudes and characteristics in managing the teaching and learning process (Suharsaputra, 2018)

\section{Conclusion}

The conclusion of this paper is that the principal has carried out good supervision at SD Negeri Tungkal Ilir, Banyuasin Regency in providing teacher competency development. Through the guidance of the principal, teachers in carrying out learning have shown performance in teaching in a better direction.

\section{References}

Ahmad, S. (2013). Ketahanmalangan Kepemimpinan Kepala Sekolah [The Headmaster's Leadership Misfortune]. Yogyakarta: Pustaka Pelicha.

Bafadal, I. (2014). Manajemen Peningkatan Mutu Sekolah Dasar: dari Sentralisasi Menuju Desentralisasi [Primary School Quality Improvement Management: from Centralization to Decentralization]. Jakarta: Bumi Aksara.

Burhanuddin. (2015). Belajar dan Pembelajaran [Learning and Instruction]. Bandung: Alfabeta.

Ekosusilo. (2013). Supervisi Pendidikan [Education Supervision]. Jakarta: Raja Graffindo Persada.

Jamal, A. M. (2009). Menjadi Guru Inspiratif, Kreatif, dan Inovatif [Becoming an Inspirational, Creative, and Innovative Teacher]. Yogyakarta: Diva Press.

Kompri. (2015). Manajemen Pendidikan 3 [Education Management 3]. Bandung: Alfabeta.

Kurniadi, R., Lian, B., \& Wahidy, A. (2021). Visionary Leadership and Organizational Culture on Teacher's Performance. Journal of Social Work and Science Education, 1(3), 249256. https://doi.org/10.52690/jswse.v1i3.112

Merlia. E. (2017). Peran Supervisi Kepala Madrasah dalam Meningkatkan Profesionalisme Guru di MTs Futuhiyah 2 Gunung Batu Bukit Kemuning Lampung Utara [The 
Journal of Social Work and Science Education

Volume 2 (1) 2021

E-ISSN: 2723-6919 P-ISSN:2746-0827

Supervision Role of Madrasah Heads in Improving Teacher Professionalism at MTs Futuhiyah 2 Gunung Batu Bukit Kemuning, North Lampung]. Jurnal Manajemen dan Administrasi Pendidikan, 2(1), 190-105.

Mulyasa. (2013). Menjadi Guru Profesional [Become a Professional Teacher]. Bandung: Remaja Rosdakarya.

Mulyasa. (2017). Menjadi Kepala Sekolah Profesional [Become a Professional School Principal]. Bandung: Remaja Rosdakarya.

Muslikhah. (2018). Peran Kepala Sekolah Sebagai Supervisor dalam Mengembangkan Profesionalisme Guru di SD Negeri 02 Gawanan [The Principal's Role as Supervisor in Developing Teacher Professionalism at SD Negeri 02 Gawanan]. Jurnal Manajemen Pendidikan, 3(2), 223-237.

Permendiknas Nomor 13 Tahun 2007 [Minister of National Education Regulation Number 13 of 2007].

Peraturan Pemerintah Nomor 19 Tahun 2015 [Government Regulation Number 19 of 2015].

Rochman, C. (2011). Pengembangan Kompetensi Kepribadian Guru [Teacher Personality Competency Development]. Jakarta: Rajawali Pers.

Samana. (2014). Profesionalisme Keguruan [Teacher Professionalism]. Yogyakarta: Kanisius.

Suharsaputra. (2018). Supervisi Pendidikan (Pendekatan Sistem Berbasis Kinerja) [Education Supervision (Performance Based Systems Approach)]. Bandung: Refika Aditama.

Sukadi. (2016). Guru Powerfull, Kunci Sukses Menjadi Guru Efektif [Powerful Teacher, Key to Success Becoming an Effective Teacher]. Bandung: Kolbu.

Supardi. (2013). Kinerja Guru [Teacher Performance]. Jakarta: Raja Grafindo Persada.

Suratman, S., Arafat, Y., \& Eddy, S. (2020). The Influence of Principal's Leadership and Teacher's Competence toward Teacher's Performance in Indonesia. Journal of Social Work and Science Education, 1(2), 96-104. https://doi.org/10.52690/jswse.v1i2.32

Yuliati, E. A. (2018). Kepemimpinan Transformasional Kepala Sekolah [Principal's Transformational Leadership]. Salatiga: Griya Media.

Yusuf, M., Fitria, H., \& Mulyadi, M. (2021). The Influence of Teacher's Supervision and Professionalism on Teacher's Performance. Journal of Social Work and Science Education, 1(3), 234-240. https://doi.org/10.52690/jswse.v1i3.110 
Journal of Social Work and Science Education

Volume 2 (1) 2021

E-ISSN: 2723-6919 P-ISSN:2746-0827

Zahroh, A. (2015). Membangun Kualitas Pembelajaran Melalui Dimensi Profesionalisme Guru [Building the Quality of Learning Through the Dimensions of Teacher Professionalism]. Bandung: Yrama Widya.

Zulaiha, D., Lian, B., \& Mulyadi, M. (2021). The Effect of Principal's Competence and Community Participation on the Quality of Educational Services. Journal of Social Work and Science Education, 1(1), 45-57. https://doi.org/10.52690/jswse.v1i1.9 